\title{
Bathymetric trends in demersal fish size: is there a general relationship?
}

\author{
Enrique Macpherson ${ }^{1}$, Carlos M. Duarte ${ }^{2}$ \\ ${ }^{1}$ Instituto de Ciencias del Mar, Paseo Nacional s/n, E-08039 Barcelona, Spain \\ ${ }^{2}$ Centro de Estudios Avanzados de Blanes, CSIC, Camino de Santa Bárbara, E- 17300 Blanes, Gerona, Spain
}

\begin{abstract}
We examined data on size of dominant demersal fish species in the SE Atlantic (44 species) and the NW Mediterranean (31 species) to determine whether there is a general tendency to increasing size towards deeper waters. Our results demonstrate significant positive size-depth relationships for most species examined ( $63 \%$ SE Atlantic and $74 \%$ NW Mediterranean). The relationships examined involved both a tendency towards greater size with increasing depth and a tendency towards smaller size towards shallower bottoms. The average ( \pm standard error) rate of increase in fish length with increasing depth was found to be $0.09 \pm 0.01 \mathrm{~cm}$ length $(\mathrm{m} \mathrm{depth})^{-1}$ for the SE Atlantic species and 0.06 $\pm 0.007 \mathrm{~cm}$ length $(\mathrm{m} \text { depth})^{-1}$ for the NW Mediterranean species. In addition, we found the slope and intercept of these relationships to scale approximately to the $3 / 4$ power of the maximum and minimum fish size respectively, showing that interspecific differences in the nature of this relationship depend on the size range of the different species. Consideration of several hypotheses to account for this general pattern suggests that it reflects a migratory (or diffusive) movement towards deeper waters during ontogeny, where fish benefit from the extended lives and lower metabolism at lower temperatures. We suggest this pattern is evolutionary in nature, and due to inherited behaviour.
\end{abstract}

\section{INTRODUCTION}

The occurrence of larger individuals of a fish species in deeper waters has been repeatedly observed in the marine (Hobson 1974, Clarke 1977, Haedrich et al. 1980, Mauchline \& Gordon 1984, Gordon \& Duncan 1985, Snelgrove \& Haedrich 1985, Middleton \& Musick 1986, Richards 1986, Gordon \& Duncan 1987) and freshwater (Helfman 1978, McCauley \& Huggins 1979, Power 1984) environments. There is, however, disagreement on both the generality and the underlying causes of this phenomenon. It is considered a 'law' by some authors (Heincke's law, Heincke 1913, cf. Cushing 1975,1976$)$ and the product of artifacts by some others (e.g. Snelgove \& Haedrich 1985, and references therein).

Advocates of its generality have postulated inter- or intraspecific competition (Helfman 1978), or predation (Cushing 1975,1976), as the reasons for the migratory or diffusive movement (Cushing 1976) underlying the phenomenon. These contentions are, however, tentative in nature, because the generality or lack of the phenomenon must be established first. Furthermore, the empirical exercise necessary to establish the gener- ality of the pattern may reveal exceptions that may help isolate specific explanations as more likely than others.

Here we seek to establish the generality of the trend towards increased fish size at greater depth based on analysis of an extensive collection of demersal fish species from the NW Mediterranean Sea and SE Atlantic Ocean. These 2 areas offer a considerable potential to achieve our goal because (1) they represent a contrast between the oligotrophic NW Mediterranean (Margalef 1985) and the highly productive Namibian coastal upwelling (Shannon 1985); (2) there is extensive information on the fish fauna and distribution within these areas; (3) the species composition present in the NW Mediterranean (e.g. Macpherson 1981) and SE Atlantic (e.g. Macpherson 1989, Mas-Riera et al. 1990) differ considerably; and (4) the species examined in each area display a wide spectrum of ontogenetic changes in food habits (Macpherson 1981, 1983). In addition, a test of the generality of the positive sizedepth relationships in 2 broadly different oceanic areas is important because these relationships have been suggested to be a geographically limited phenomenon (Snelgrove \& Haedrich 1985). We first examine the ranges in fish size and the depth occupied by the 
different species and quantify the strength and significance of the size-depth relationships. The generality of the pattern was then assessed by comparing the number of species showing significant positive sizedepth relationships with that expected under the null hypothesis that fish size is independent of depth. We then use the results obtained to assess the likelihood of a set of hypothetical mechanisms to account for the pattern that may provide a useful reference for future research

\section{METHODS}

The data on the SE Atlantic demersal fish communities were collected during 4 cruises of $20 \mathrm{~d}$ within the period (winter and summer) from September 1987 to January 1989 along the continental shelf of the Benguela upwelling region off Namibia, between 23 and $30^{\circ} \mathrm{S}$. The area sampled consisted of sea-bottoms between 50 and $1000 \mathrm{~m}$ depth. Fishing stations were determined by a stratified random design (Macpherson et al. 1985), and ca 70 stations were sampled from a commercial stern trawl (2 warps, headlines $>20 \mathrm{~m}$, and heights between 2 and $4 \mathrm{~m}, 20 \mathrm{~mm}$ mesh size) on each cruise. Fish were collected by means of bottom trawl nets during daytime to avoid possible vertical migration at night. Each haul consisted of $30 \mathrm{~min}$ trawls at 3 knots, thereby sweeping 1.5 nautical miles. For each haul, the total number and weight of fish collected was calculated for each species, and all fish collected (or a subsample of 250 when more than 300 were collected) were measured to calculate the average size (total fish length, in $\mathrm{cm}$ ) of the fish within each sample. We used the arithmetic mean, rather than median or geometric mean, fish size to represent the central tendency in the samples because fish sizes (i.e. lengths) were normally distributed within samples (average coefficient of variation $18.9 \% \pm 1.4 \mathrm{SE}$ ).

The data on demersal fish communities from the NW Mediterranean (about 40 to $42^{\circ} \mathrm{N}$ along the Catalan coast) were gathered from seasonal surveys carried out by our laboratories from 1976 to 1985 . The area sampled consisted of sea-bottoms between 25 and $900 \mathrm{~m}$ depth. Sampling methods were similar to those used to sample the SE Atlantic fish community, but the sampling stations were on transects spaced out perpendicular to the coast, and the commercial gear used was somewhat smaller $(2$ warps, headline $>10 \mathrm{~m}$, heights 2 to $4 \mathrm{~m}, 8 \mathrm{~mm}$ mesh size).

To achieve sufficient statistical certainty to test our hypotheses we limited the data sets used to species present in $>10$ trawls containing at least 3 individuals per trawl. The resulting data sets consist of 44 species from the SE Atlantic and 31 species from the NW
Mediterranean (Tables 1 \& 2). The depths sampled encompassed the depth range of most species. Because we found no evidence of seasonal differences in fish size-depth relationships, data from all surveys were pooled (Tables 1 \& 2). The strength of size-depth relationships was described by the Pearson correlation coefficient between the average size of the species in each sample and sampling depth and the relationships were described by fitting reduced major axis linear regressions to the data (Till 1974).

\section{RESULTS}

The fish species studied occupied very different depth ranges, irrespective of fish size (Tables 1 \& 2). Length frequencies for each of the species captured in the different trawls showed very small skewness, as reflected in the very small $(<20 \%)$ coefficients of variations of fish size (Fig. 1). Thus, the average length found for each species is an appropriate descriptor of the central tendency in their size in particular samples. Correlations between fish size and depth ranged from negative $(-0.62, p<0.05$, for Raja leopardus; Table 2) to strongly positive $10.97, \mathrm{p}<0.05$, for Dentex macrophthalmus; Table 2). There were no obvious phylogenetic patterns in the strength and nature of the relationships found, except (1) the tendency of species of the genus Raja to show negative, rather than positive size-depth relationships (Table 2); and (2) the low correlation coefficients of Anguilliformes species in both areas (Tables 1 \& 2). The average (and standard error) correlation coefficients were $0.41 \pm 0.05$ for the SE Atlantic and $0.63 \pm 0.05$ for the NW Mediterranean fish species, although there was considerable variation in the strength of the correlation coefficient (Fig. 2). We found $63 \%$ and $74 \%$ of the correlations to be positive and significant for the SE Atlantic and NW Mediterranean fish species, respectively (Tables $1 \& 2$ ). The average correlation coefficients obtained are significantly greater than expected by chance alone i.e. $H_{0}: r=0$, $t$-test, $p<0.001)$. Moreover, the proportion of significant $(p<0.05)$, positive size-depth correlation coefficients were much greater than those expected by chance alone (i.e. $5 \%$ ). Significant relationships between mean fish size and depth may result from positive relationships between maximum fish and depth (i.e. 'bigger-deeper', e.g. Polloni et al. 1979), negative relationships between minimum fish size and depth (i.e. smaller-shallower, e.g. Middleton \& Musick 1986), or both. We tested whether the positive relationships between average fish size and depth reflected 'biggerdeeper' or 'smaller-shallower' phenomena by comparing the correlation coefficients between minimum and maximum size and depth for each species. This com- 
parison revealed no consistent tendency (Wilcoxon ranked sign test, $p>0.10$ ) for one phenomenon to dominate over the other, thereby indicating that the general increase in average fish size with depth in- volves, for the set of species examined here, both processes ('bigger-deeper' and 'smaller-shallower').

Regression analyses (Size $=a+b$ Depth) showed that the average ( \pm standard error) rate of increase in

Table 1. Summary statistics describing the size, depth distribution, and size-depth relationship of NW Mediterranean demersal fish species, $r$ : Pearson size-depth correlation coefficient $(+$ : significant correlation coefficient, $p<0.05$; NS: non-significant correlation coefficient, $\mathrm{p}>0.05$ ); size: Average, standard deviation (SD), and range (min, max) for the mean total length (cm) for the different samples; depth: average, standard deviation (SD), and range (min, max) of the depths (m) where the different species were collected; also shown are the major axis regression coefficients for the equation Size $a+b$ Depth, and the number of samples (Ns) and number of individuals measured (Nt) for each species

\begin{tabular}{|c|c|c|c|c|c|c|c|c|c|c|c|c|c|c|}
\hline Species & $r$ & & Size & SD & Min & Max & Depth & $\mathrm{SD}$ & Min & Max & $a$ & $b$ & Ns & $\mathrm{Nt}$ \\
\hline \multicolumn{15}{|l|}{ Order Squaliformes } \\
\hline Etmopterus spinax & 0.67 & + & 17.9 & 3.7 & 13.8 & 25.4 & 464 & 91 & 334 & 648 & 14.2 & 0.041 & 18 & 194 \\
\hline \multicolumn{15}{|l|}{ Order Carcharhiniformes } \\
\hline Galeus melastomus & 0.84 & + & 21.5 & 8.6 & 12.3 & 44.3 & 401 & 125 & 260 & 650 & 12.9 & 0.069 & 28 & 596 \\
\hline Scyliorhinus canicula & 0.21 & NS & 27.0 & 8.6 & 13.6 & 42.0 & 245 & 60 & 160 & 370 & 18.4 & 0.143 & 28 & 452 \\
\hline \multicolumn{15}{|l|}{ Order Chimaeriformes } \\
\hline Chimaera monstrosa & 0.65 & + & 35.7 & 8.0 & 25.8 & 50.3 & 421 & 69 & 370 & 610 & 27.7 & 0.116 & 10 & 115 \\
\hline \multicolumn{15}{|l|}{ Order Anguiliformes } \\
\hline Conger conger & 0.18 & NS & 46.4 & 5.7 & 36.5 & 54.0 & 256 & 84 & 80 & 425 & 40.7 & 0.068 & 14 & 135 \\
\hline Gnathophis mystax & 0.47 & + & 27.0 & 3.5 & 20.7 & 32.1 & 267 & 47 & 222 & 352 & 23.4 & 0.075 & 12 & 180 \\
\hline \multicolumn{15}{|l|}{ Order Notacanthiformes } \\
\hline Notacanthus bonapartei & 0.18 & + & 21.6 & 2.9 & 15.6 & 26.1 & 439 & 87 & 246 & 550 & 18.7 & 0.033 & 10 & 110 \\
\hline \multicolumn{15}{|l|}{ Order Lophiiformes } \\
\hline Lophius budegassa & 0.28 & NS & 17.3 & 6.1 & 8.1 & 29.1 & 231 & 84 & 87 & 430 & 11.2 & 0.073 & 15 & 240 \\
\hline Lophius piscatorius & 0.05 & NS & 24.9 & 4.7 & 18.0 & 34.6 & 255 & 47 & 209 & 358 & 20.1 & 0.100 & 16 & 206 \\
\hline \multicolumn{15}{|l|}{ Order Gadiformes } \\
\hline Antonogadus megalokynodon & 0.89 & + & 8.7 & 1.5 & 6.5 & 11.0 & 346 & 85 & 220 & 463 & 7.2 & 0.018 & 16 & 254 \\
\hline Coelorhynchus coelorhynchus & 0.83 & + & 15.8 & 6.4 & 8.4 & 27.0 & 405 & 94 & 280 & 610 & 9.4 & 0.068 & 22 & 236 \\
\hline Hymenocephalus italicus & 0.65 & + & 14.6 & 2.0 & 8.7 & 16.6 & 538 & 116 & 340 & 759 & 12.6 & 0.017 & 16 & 258 \\
\hline Merluccius merluccius & 0.85 & + & 21.2 & 8.6 & 11.3 & 37.9 & 181 & 137 & 22 & 455 & 12.6 & 0.063 & 25 & 2961 \\
\hline Micromesistius poutassou & 0.90 & + & 22.6 & 5.3 & 12.2 & 31.6 & 286 & 97 & 118 & 460 & 17.3 & 0.054 & 19 & 896 \\
\hline Molva macrophthalma & 0.87 & + & 24.2 & 6.3 & 15.9 & 33.0 & 298 & 74 & 230 & 450 & 17.9 & 0.085 & 16 & 392 \\
\hline Nezumia aequalis & 0.64 & + & 19.1 & 3.7 & 11.7 & 22.7 & 607 & 62 & 540 & 759 & 15.4 & 0.059 & 22 & 336 \\
\hline Phycis blennoides & 0.77 & + & 21.1 & 2.5 & 16.7 & 25.2 & 360 & 105 & 218 & 540 & 18.7 & 0.023 & 20 & 644 \\
\hline Trachyrhynchus trachyrhynchus & 0.79 & + & 20.4 & 3.9 & 15.4 & 29.2 & 524 & 151 & 242 & 750 & 16.4 & 0.026 & 24 & 808 \\
\hline Trisopterus luscus & 0.15 & NS & 13.7 & 3.6 & 5.9 & 19.0 & 118 & 37 & 66 & 180 & 10.1 & 0.096 & 22 & 1004 \\
\hline \multicolumn{15}{|l|}{ Order Zeiformes } \\
\hline Capros aper & 0.82 & + & 7.0 & 1.8 & 4.4 & 9.1 & 244 & 123 & 110 & 450 & 5.2 & 0.014 & 10 & 314 \\
\hline \multicolumn{15}{|l|}{ Order Scorpaeniformes } \\
\hline Helicolenus dactylopterus & 0.86 & + & 12.4 & 3.2 & 8.4 & 19.2 & 275 & 76 & 180 & 400 & 9.2 & 0.043 & 26 & 752 \\
\hline Trigla lyra & 0.29 & NS & 12.8 & 2.4 & 8.7 & 15.6 & 279 & 126 & 185 & 610 & 10.4 & 0.019 & 12 & 130 \\
\hline \multicolumn{15}{|l|}{ Order Perciformes } \\
\hline Epigonus telescopus & 0.39 & NS & 9.2 & 2.8 & 6.5 & 16.0 & 424 & 82 & 259 & 537 & 6.4 & 0.034 & 10 & 120 \\
\hline Pagellus erythrinus & 0.56 & + & 19.9 & 4.2 & 12.8 & 25.6 & 51 & 26 & 22 & 110 & 15.7 & 0.159 & 28 & 914 \\
\hline Pagellus acarne & 0.82 & + & 20.7 & 3.5 & 14.4 & 26.0 & 66 & 36 & 26 & 140 & 17.3 & 0.095 & 15 & 664 \\
\hline Mullus barbatus & 0.65 & + & 13.4 & 2.1 & 10.9 & 18.5 & 72 & 33 & 26 & 130 & 11.3 & 0.064 & 30 & 1770 \\
\hline Mullus surmuletus & 0.88 & + & 16.5 & 2.1 & 13.5 & 20.2 & 63 & 51 & 12 & 182 & 14.3 & 0.041 & 20 & 500 \\
\hline Trachurus trachurus & 0.96 & + & 15.6 & 7.0 & 7.6 & 27.8 & 85 & 50 & 22 & 164 & 8.6 & 0.141 & 22 & 1282 \\
\hline \multicolumn{15}{|l|}{ Order Pleuronectiformes } \\
\hline Citharus macrolepidotus & 0.71 & + & 15.2 & 1.4 & 11.6 & 18.1 & 89 & 29 & 50 & 140 & 13.8 & 0.050 & 30 & 1250 \\
\hline Simphurus nigrescens & 0.95 & + & 8.7 & 0.5 & 8.2 & 9.3 & 302 & 78 & 222 & 435 & 8.2 & 0.006 & 20 & 584 \\
\hline Lepidorhombus boscu & 0.85 & + & 13.6 & 4.4 & 8.1 & 20.0 & 263 & 60 & 178 & 430 & -5.5 & 0.073 & 10 & 111 \\
\hline
\end{tabular}




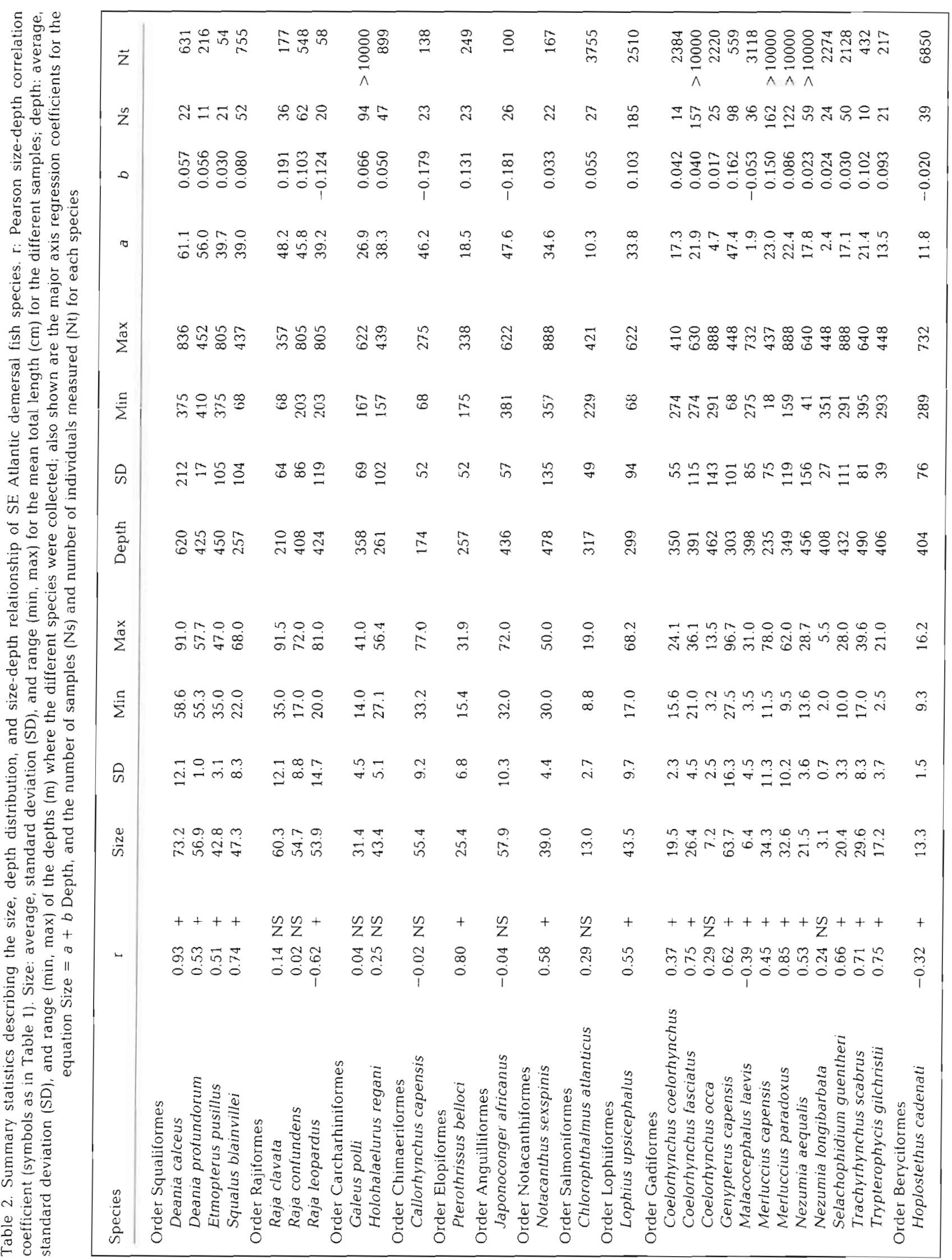




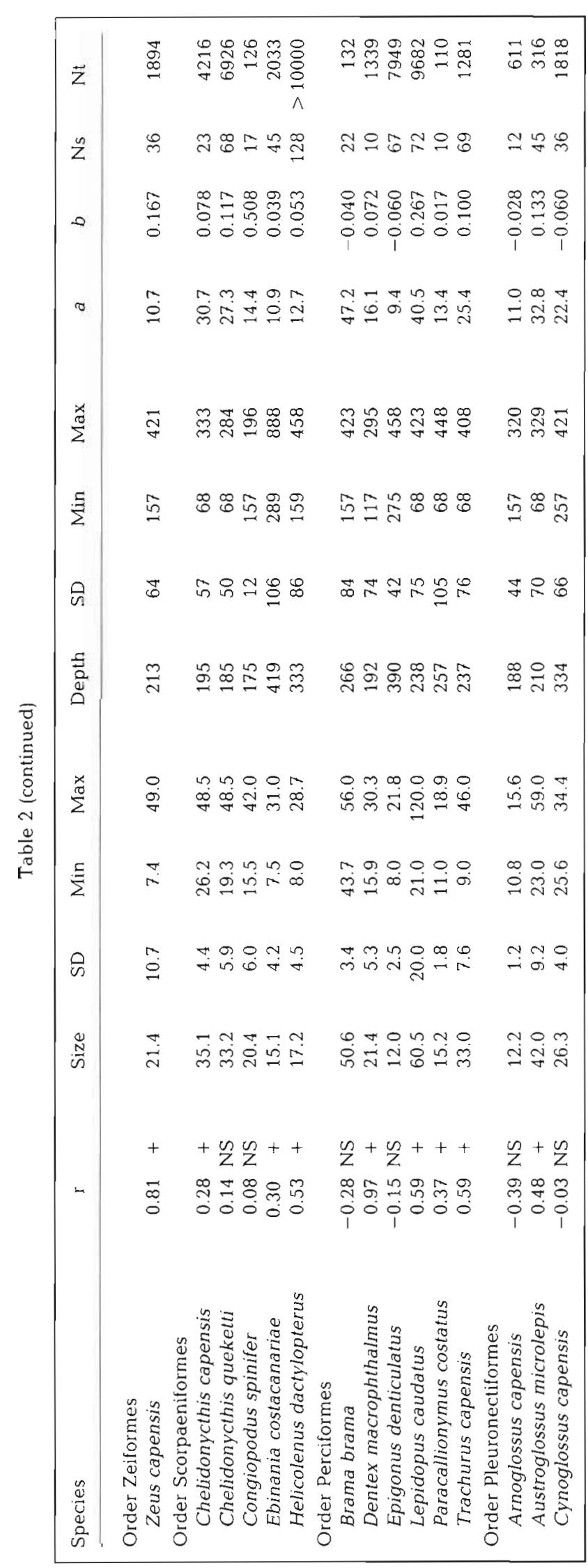

fish length with increasing depth was $0.09 \pm 0.01 \mathrm{~cm}$ length (m depth) ${ }^{-1}$ for the SE Atlantic species and 0.06 $\pm 0.007 \mathrm{~cm}$ length ( $\mathrm{m}$ depth$)^{-1}$ for the NW Mediterranean species. The relationships between fish size and sampling depth differ considerably (Fig. 3), both in slope and intercept (Fig. 4), among species. However, the variability in regression coefficients (i.e. slope and intercept; Fig. 4) of these relationships is not random, but is closely related to the size range of the species (Tables 1 \& 2). Species attaining large sizes show a steeper increase in fish size with depth (Fig. 5). Similarly, large species (i.e. those displaying relatively large sizes in all samples) are, as expected, larger at the upper end of their depth range than are smaller species. The size-dependence of the depth-size relationships is best described by the allometric equations

$$
\begin{gathered}
\text { log Slope }(\mathrm{cm} \text { length } / \mathrm{m} \text { depth })=-2.52+ \\
0.86( \pm 0.12) \log \text { Maximum size }(\mathrm{cm}) \\
\mathrm{R}^{2}=0.43, \mathrm{p}<0.0001
\end{gathered}
$$

and

$$
\begin{aligned}
& \log \text { Intercept }(\mathrm{cm})=0.26+ \\
& 0.87( \pm 0.057) \log \text { Minimum size }(\mathrm{cm}) \\
& \mathrm{R}^{2}=0.78, \mathrm{p}<0.0001
\end{aligned}
$$

showing that the rate of increase in fish length with increasing depth is scaled approximately to the $3 / 4$ power of maximum fish length. The same scale is also observed in the second relationship. These relationships were similar for both the SE Atlantic and NW Mediterranean species (ANCOVA, t-test, $p>0.05$ ),

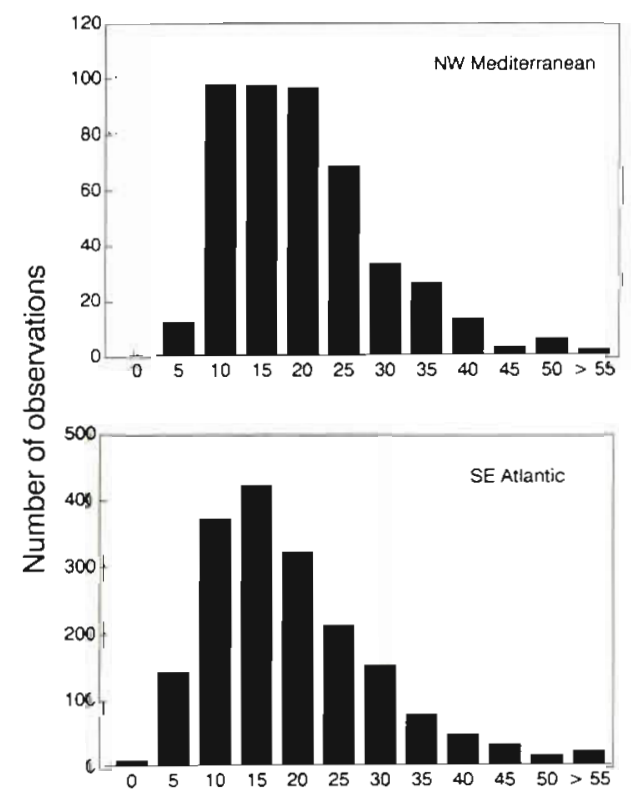

Size coefficient of variation (\%)

Fig. 1. Frequency distribution of the size (length) coefficient of variation for the different species observed in each sample 


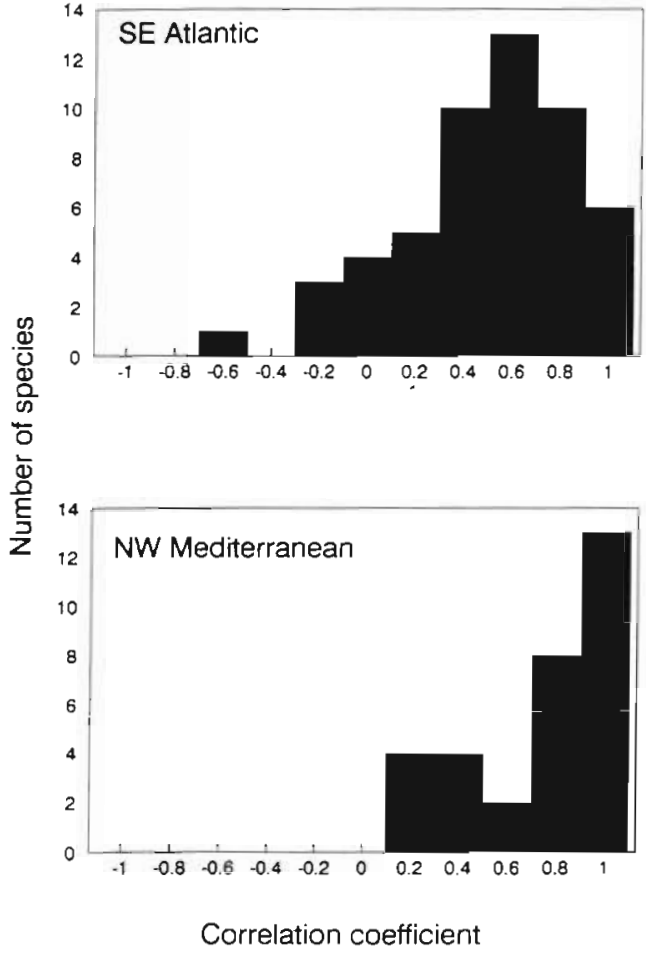

Fig. 2. Frequency distribution of the Pearson correlation coefficient between fish size and sampling depth for the SE Atlantic and NW Mediterranean demersal fish species

although there was a marginally significant tendency (ANCOVA, $p=0.048$ ) for SE Atlantic species to have greater size-depth intercepts than NW Mediterranean species of similar minimum size (Fig. 5).

\section{DISCUSSION}

The results obtained support the generality of the phenomenon of increasing fish size with increasing depth for both the NW Mediterranean and SE Atlantic demersal fish species; the proportion of positive significant size-depth relationships is much greater than that expected by chance. However, the pattern differs between species, as reflected in the variability of the size-depth relationships (Figs. 3 \& 4). Inter-specific differences in the patterns are a matter of scaling differences in the size range of the species, as demonstrated by the scaling of both slope and intercept to approximately the $3 / 4$ power of maximum and minimum fish size respectively for both the SE Atlantic and NW Mediterranean species (Fig. 5). Thus, we conclude that there is, at least for the areas studied, a tendency for size to increase with depth in most demersal fish. The rate of this increase depends on the size range of the particular species.

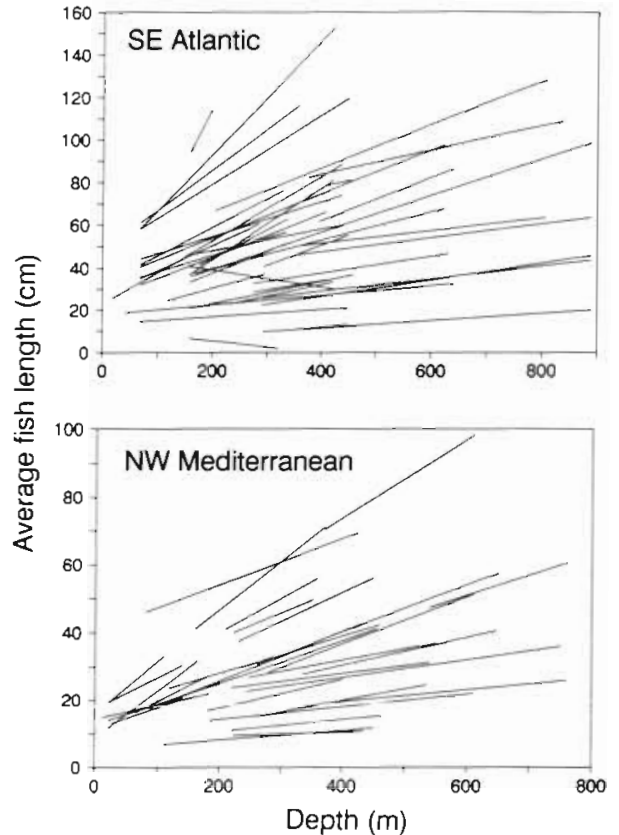

Fig. 3. Major axis regression lines describing the relationship between the average length of each species in a sample and sampling depth for the species studied
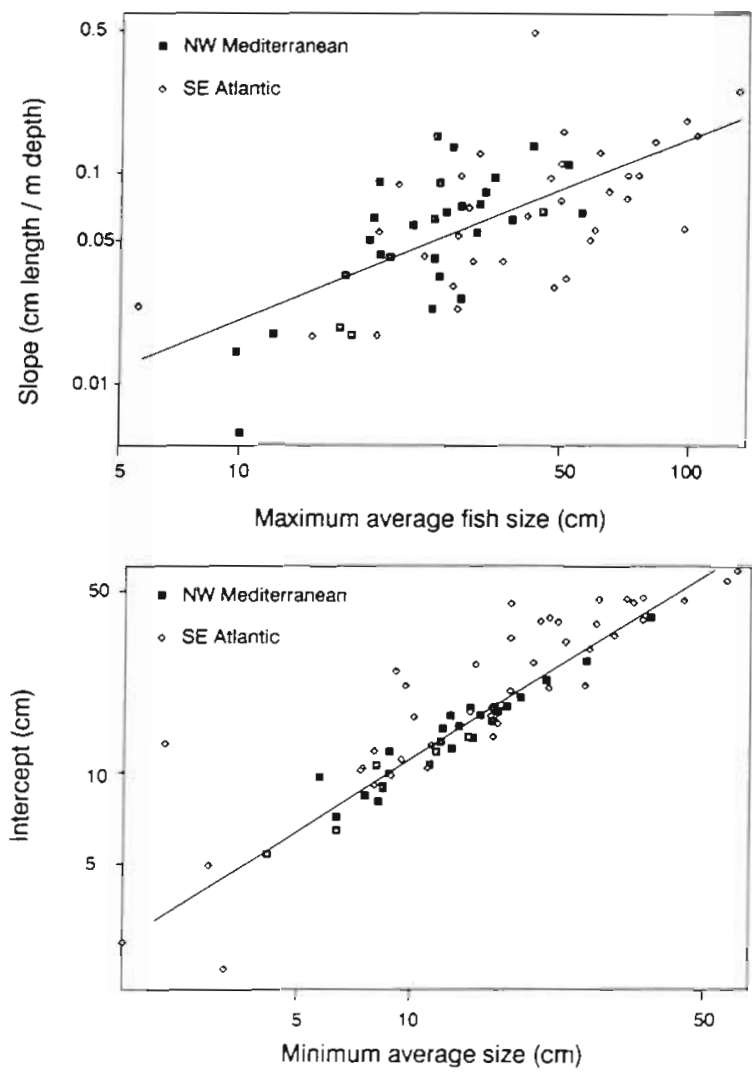

Fig. 4. Frequency distribution of the major axis regression coefficients describing the relationship between fish size and sampling depth for the SE Atlantic and NW Mediterranean demersal fish species [i.e. Length $(\mathrm{cm})=$ Intercept + Slope Depth $(\mathrm{m})]$ 
Fig. 5. Relationship between major axis regression coefficients describing the relationship between fish size and sampling depth for the SE Atlantic and NW Mediterranean demersal fish species [i.e. Length $(\mathrm{cm})=$ Intercept + Slope Depth $(\mathrm{m})]$, and the maximum and minimum average length of the species. Regression lines correspond to Eqs. (1) and (2)
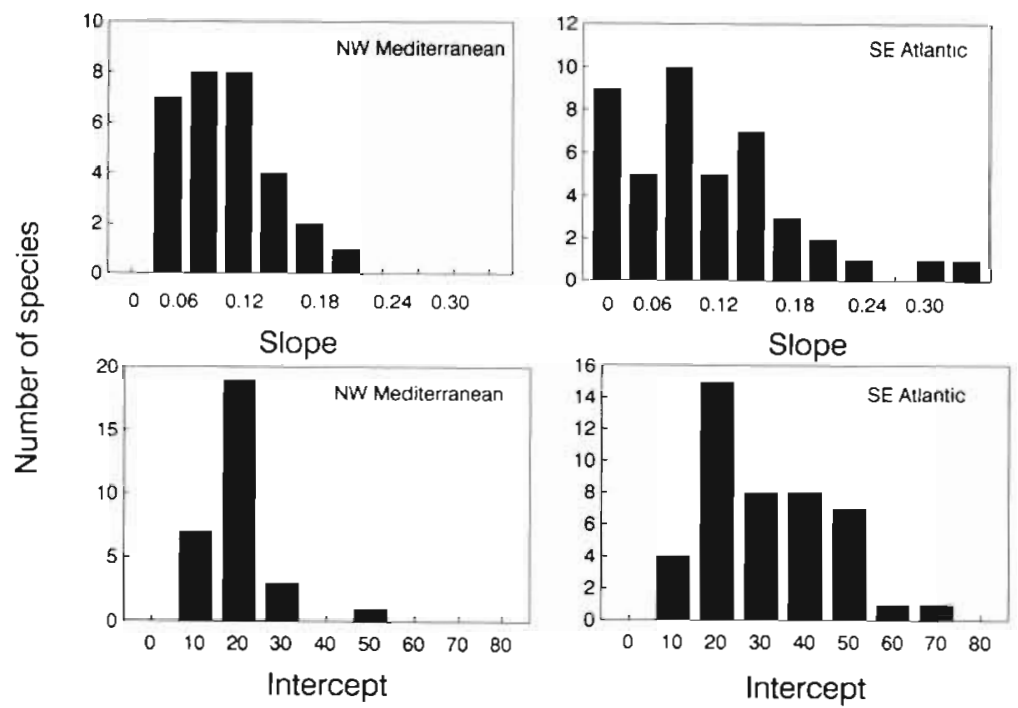

There are, however, some exceptions to this pattern as a general rule, such as the negative relationships observed for some species of the genus Raja, and the lack of a relationship between fish size and depth for, among others, some Selachian and Anguilliform species (Tables $1 \& 2$ ). Some of these exceptions could be attributable to life-history peculiarities of these species (e.g. sexual depth displacement in Conger conger; Cau \& Manconi 1984) or the biogeographical distribution of some of these species relative to the areas sampled. For instance, some species (e.g. Arnoglossus capensis, Cynoglossus capensis, Chelidonycthis queketti, Congiopodus spinifer) were sampled close to their distributional limits (cf. Macpherson 1989), where reduced recruitment restricts the population to large individuals (Macpherson unpubl.). However, lack of detailed data on the life-history of some of these species precludes further examination of this influence on the pattern.

The preponderance of the positive size-depth relationship in fish species may reflect a fundamental aspect of fish life history, or it may be the result of sampling artifacts (e.g. size-dependent catchability; cf. Pearcy et al. 1982), or selective fishing pressure. However, sampling artifacts and selective fishing pressure are, according to Snelgrove \& Haedrich (1985), unlikely to account for the generality of the relationship because (1) sampling gear and methods were the same for both shallow and deep trawls; and (2) fishing pressure is intense in slope and shelf of both areas (cf. Bas et al. 1985. Crawford et al. 1987), but the distribution of fishing effort is unlikely to account for the preponderance of the relationship in the set of species examined. A further question is whether the relationship reflects a homogeneous tendency to increase fish size towards deeper water or whether it reflects, instead, a 'biggerdeeper' (Polloni et al. 1979), or 'smaller-shallower'
(Middleton \& Musick 1986) phenomenon. Our results, however, revealed no evidence of one phenomenon to dominate over the other, thereby indicating that the general increase in average fish size with depth reflects a homogeneous tendency to increase fish size with depth.

The general nature of the depth-size relationship observed must derive, therefore, from migratory (or diffusive) movements from shallow to deeper water during fish ontogeny (Cushing 1976). The observation of smaller fish closer to shore should involve either an inshore migration of adult fish during the spawning season (e.g. Merluccius capensis; Crawford et al, 1987 and references therein) or the in-shore migration (or drift) of early life-stages (Cushing 1975, 1976, Norcross \& Shaw 1984, Campana et al. 1989, Kim \& Kendall 1989, Lough \& Bolz 1989, Marchand \& Masson 1989, Marliave 1989). The data available for some NW Mediterranean (Sabatés 1990) and SE Atlantic (Olivar 1990) species do not indicate any substantial difference in the distribution of adult fish and larvae, suggesting that the migration (or drift) there must involve juveniles or larvae, rather than adults.

The depth range occupied by fish species is influenced by physiological constraints (Somero et al. 1983). However, the positive depth-size relationship, which determines the positioning of the fish within their depth range, appears to reflect a general behaviourial pattern. The positioning of smaller, younger individuals in shallower water and their movement towards deeper water during ontogeny must involve a substantial advantage. These advantages may involve (1) bathymetric differences in food availability; (2) avoidance of inter- or intra-specific competition and predation (Cushing 1975, 1976, Helfman 1978), and (3) physiological differences associated with increased depth. Available information on bathymetric changes in the abundance of the most common preys of the fish 
species considered (e.g. polychaetes, euphausiids, sergestids, myctophids; Macpherson 1981, 1983) reveals no consistent bathymetric pattern in their abundance (e.g. Thiel 1978, 1982, Hulley \& Prosch 1987 Olivar \& Barangé 1990, Barangé \& Stuart 1991). We believe that bathymetric changes in food availability may explain differences in demersal fish biomass, but not size structure. If bathymetric changes in prey availability were causing the phenomenon, predator size classes exploiting the same food resource should show a coherent depth distribution, which was not evident in our data. Competition, both intra- and interspecific, has been observed to influence the size distribution of coral-reef fishes (e.g. Jones 1984, Shulman \& Ogden 1987). These displacements, however, are referred to the home-range of the organisms, whereas the bathymetric size segregation described here involves horizontal scales of dozens of kilometres. Further, displacements derived from competition need not involve a consistent directionality (i.e., all large fish displaced towards deeper waters). Likewise, avoidance of predation at the shallower depths inhabited by juvenile fish of littoral species is conceivable, but is difficult to argue for fish occupying the continental shelf and slope. In addition, predation appears to be a significant source of mortality for only a few (e.g. Merluccius capensis; Roel \& Macpherson 1988) of the species studied here (Macpherson 1981, 1983).

The applicability of a similar - except for differences of scale - size-depth relationship to taxonomically distant fish (Fig. 5), differing widely in resources and habitats exploited suggests that positive size-depth relationships must have important evolutionary implications. Positive size-depth relationships imply a migration toward deeper waters during ontogeny (Cushing 1976). Larval and juvenile stages often occur in shallower, warmer waters, whereas older fish tend to exist at greater, colder, depths (Cushing 1976).

Temperature is a major factor in fish metabolism (Fry 1971, Somero et al. 1983) and behaviourial responses (Brett 1970, 1979, Garside 1970, Kinne 1970a, b). Large fish show greater preference for colder waters than small fish of the same species (Magnuson et al. 1979, McCauley \& Huggins 1979, Jobling 1981). Accordingly, early life stages live in warmer waters, where food supply and growth rates are often greater (e.g. Jones 1976) and older fish live in colder waters, where they may benefit from lower metabolic cost and greater longevity (Love 1970, 1980). Reduced metabolic cost implies that a greater fraction of the resources consumed can be allocated to reproduction. The potential for relatively greater reproductive effort and greater longevity may significantly increase the total number of offspring produced by the fish and, consequently, total fish reproductive output.
That positive size-depth relationships may partially reflect the associated temperature gradient also accounts for the occurrence of positive size-depth relationships over a much narrower depth range in freshwater fish (Helfman 1978, McCauley \& Huggins 1979, Power 1984). In freshwater there are often temperature gradients within a few meters in depth similar to those present in the sea over hundreds of meters. The positive size-depth relationship would, therefore, be analogous to the Bergman law that describes the increase in mammal species size towards higher, colder, latitudes (e.g. Margalef 1974). However, this explanation accounts for a depth-size gradient only where temperature decreases significantly with increasing depth. While this occurs within the depth range sampled in the SE Atlantic (e.g. from $13^{\circ} \mathrm{C}$ at $100 \mathrm{~m}$ to $5^{\circ} \mathrm{C}$ at $1000 \mathrm{~m}$; Masó \& Manriquez 1987), temperatures in the NW Mediterrancan remain constant (at ca. $12^{\circ} \mathrm{C}$ ) below 160 to $200 \mathrm{~m}$ depth (e.g. Salat \& Font 1987). Maintenance of the pattern in the NW Mediterranean species occurring below $200 \mathrm{~m}$ requires, therefore, a different explanation. The only evident factor that shows a homogeneous change with increasing depth is hydrostatic pressure. However, that hydrostatic pressure influences fish, directly or indirectly, is unlikely (e.g. Somero et al. 1983). Although both depth and size appear to have an important influence on fish metabolism (Siebenaller et al. 1982, Sullivan \& Somero 1983, Torres \& Somero 1988, Childress et al. 1990), available information alone does not suffice to unambiguously elucidate the role of fish metabolism on the depth-size relationship described here.

It may be that the size-depth relationship observed represents an evolutionary, rather than physiological, response of the fish, independent of the depth changes in habitat conditions in the particular location inhabited by the fish. The generality of the positive depthsize relationship would then match the global generality of decreasing temperatures as depth increases. In addition, an evolutionary (i.e. genetic, rather than environmental) source of the positive depth-size relationship would explain the apparent anomalous relationship in the Mediterranean, where temperature remains homogeneous below $200 \mathrm{~m}$, because the NW Mediterranean fauna appears to have an Atlantic origin (e.g. Margalef 1974). Moreover, many fish species experience a general ontogenetic change of the nervous system, which increases the light and sound thresholds of the fish; such changes allows adult fish to exploit waters deeper than those suitable for smaller individuals (e.g. Lombarte 1990, Mas-Riera 1990).

The inference of the factor(s) causing the observed pattern is elusive, for cause and effect are not easily distinguished (i.e. the influence of being larger versus 
the influence of living deeper). Thus, we can see no simple test of any of the plausible causes. However, it is clear that increased knowledge of the implications of habitat depth and organism size on fish metabolism (e.g. metabolic and growth responses to pressure and temperature), behaviour (e.g. migrations during fish ontogeny), and life-history (e.g. total reproductive output) should provide insight into the evolutionary benefit that explains the generality of the size-depth relationship.

In summary, we provide evidence for the existence of a general tendency for the size of demersal fish species to increase with increasing depth. In addition, the scaling of the slope and intercept of these relationships to approximately the $3 / 4$ power of the maximum and minimum fish size, respectively, show among-species differences in the nature of this relationship to depend on the size range displayed by the different species. Consideration of hypotheses to account for this general pattern suggests that it reflects a movement towards deeper waters during ontogeny, where fish benefit from the extended lives and lower metabolic cost of life. We suggest this pattern is evolutionary in nature and may largely depend on inherited behaviour.

Acknowledgements. We thank Jaume Fernández Borrás for helpful discussion and the anonymous reviewers and the Marine Resources Research Group of the Instituto de Ciencias del Mar of Barcelona for stimulating criticisms

\section{LITERATURE CITED}

Barangé, M., Stuart, V. (1991). Distribution patterns, abundance and population dynamics of the euphasiids Nictiphanes capensis and Euphausia hanseni in the Northern Benguela upwelling system. Mar. Biol. (in press)

Bas, C., Macpherson, E., Sardá, F. (1985). Fishes and fishermen. The explotaible trophic levels. In: Margalef, R. (ed.) Key environments. Western Mediterramean. Pergamon Press, Oxford, p. 296-316

Brett, J. R. (1970). Temperature: Animals: Fishes, Functional responses. In: Kinne, O. (ed.) Marine ecology, Vol. I, Part 1. Environmental factors. Wiley \& Sons, London, p. 515-560

Brett, J. R. (1979). Environmental factors and growth. In: Hoar, W. S., Randall, D. J., Brett, J. R. (eds.) Fish physiology, Vol. VIII. Academic Press, New York, p. 599-675

Cau, A., Manconi, P. (1984). Relationship of feeding, reproductive cycle and bathymetric distribution in Conger conger. Mar. Biol. 81: 147-151

Campana, S. E., Smith, S. J., Hurley, P. C. F. (1989). An agestructured index of cod larval drift and retention in the waters off southwest Nova Scotia. Rapp. P.-v. Réun. Cons. int. Explor. Mer 191: 50-62

Childress, J. J., Cowles, D. L., Favuzzi, J. A., Mickel, T J. (1990). Metabolic rates of deep-sea decapod crustaceans decline with increasing depth primarily due to the decline in temperature. Deep-Sea Res. 37: 929-949

Clarke, R. D. (1977). Habitat distribution and species diversity of chaetodontid and pomacentrid fishes near Bimini, Bahamas. Mar. Biol. 40: 277-289.
Crawford, R. J. M., Shannon, L. V., Pollock, D. E. (1987). The Benguela ecosystem. 4. The major fish and invertebrate resources. In: Barnes, $M$. (ed.) Oceanography and marine biology. An annual review, 25. University Press, Aberdeen, p. 353-505

Cushing, D. H. (1975). Marine ecology and fisheries. Cam bridge Univ. Press, Cambridge

Cushing, D. H. (1976). Biology of fishes in the pelagic community. In: Cushing, D. H., Walsh, J. J. (eds.) The ecology of the seas. Blackwell, Oxford, p. 317-340

Fry, F. E. J. (1971). The effect of environmental factors on the physiology of fish. In: Hoar, W. S., Randall, D. J. (eds.). Fish physiology. Vol. VI, Environmental relations and behavior. Academic Press, New York, p. 1-98

Garside, E. T. (1970). Temperature: Animals: Structural responses. In: Kinne, O. (ed.) Marine ecology, Vol. I, Part 1 Environmental factors. Wiley \& Sons, London, p. 561-616

Gordon, J. D. M., Duncan, J. A. R. (1985). The ecology of the deep-sea benthic and benthopelagic fish on the slopes of the Rockall Trough, Northeastern Atlantic. Prog Oceanogr. 15: 37-69

Gordon, J. D. M., Duncan, J. A. R. (1987). Deep-sea bottomliving fishes at two repeat stations at 2200 and $2900 \mathrm{~m}$ in the Rockall Trough, northeastern Atlantic Ocean. Mar. Biol. 96: 309-325

Haedrich, R. L., Rowe, G. T., Polloni, P. T. (1980). The megabenthic fauna in the deep sea south of New England USA. Mar Biol. 57: 165-179

Heincke, F. (1913). Untersuchungen über die Scholle, Generalbericht I, Schollenfischerei und Schonmaßregeln. Vorläufige kurze Übersicht über die wichtigsten Ergebnisse des Berichts. Rapp. P.-v. Réun. Cons, int. Explor Mer 16: 1-70

Helfman, G. S. (1978). Patterns of community structure in fishes: summary and overview. Environ. Biol. Fish. 3: $129-148$

Hobson, E. S. (1974). Feeding relationships of teleostean fishes on coral reefs in Kona, Hawaii. Fish. Bull. U.S. 72 915-1031

Hulley, P. A., Prosch, R. M. (1987). Mesopelagic fish derivatives in the Southern Benguela upwelling region. In: Payne, A. I. L., Gulland, J. A., Brink, K. H. (eds.) The Benguela and comparable ecosystems. S. Afr. J. mar. Sci. 5: $597-611$

Jobling, M. (1981). Temperature tolerance and the final preferendum rapid methods for the assessment of optimun growth temperatures. J. Fish Biol. 19: 439-455

Jones, G. P. (1984). Population ecology of the temperate reef fish Pseudolabrus celidotus Bloch \& Schneider (Pices: Labridae). I. Factors influencing recruitment. J. exp. mar. Biol. Ecol. 75: 277-303

Jones, R. (1976). Growth of fishes. In: Cushing, D. H., Walsh, J J. (eds.) The ecology of the seas. Blackwell, Oxford, p 251-279

Kim, S., Kendall, A. W. Jr (1989). Distribution and transpart of larval walleye pollock (Theragra chalcogramma) in Shelikof Strait, Gulf of Alaska, in relation to water movement, Rapp. P.-v. Réun. Cons. int. Explor. Mer 191. 127-136

Kinne, O. (1970a). Temperature: General introduction. In Kinne, O. (ed.) Marine ecology, Vol. I, Part 1, Environmental factors. Wiley \& Sons, London, p. 321-346

Kinne, O. (1970b). Temperature: Animals: Invertebrates. In: Kinne, O. (ed.) Marine ecology, Vol. I, Part I, Environmental factors. Wiley \& Sons, London, p. 407-514

Lombarte, A. (1990). Efectos ambientales y filogenéticos en la morfología del laberinto auditivo de los peces teleósteos. Ph. D. thesis, Univ. Barcelona

Lough, R. G., Bolz, G. R. (1989). The movement of cod and 
haddock larvae onto the shoals of Georges Bank. J. Fish Biol. 35 (suppl. A) : 71-79

Love, R. M. (1970). The chemical biology of fishes. Academic Press, London

Love, R. M. (1980). The chemical biology of fishes. Vol. 2: Advances 1968-1977. Academic Press, London

Macpherson, E. (1981). Resource partitioning in a Mediterranean demersal fish community. Mar. Ecol. Prog. Ser. 4: 183-193

Macpherson, E. (1983). Ecología trófica de peces en las costas de Namibia. I Hábitos alimentarios. Res. Exp. Cient. 11: 81-137

Macpherson, E. (1989). Influence of geographical distribution, body size and diet on population density of benthic fishes off Namibia (South West Africa). Mar. Ecol. Prog. Ser. 50 295-299

Macpherson, E., Roel, B., Morales, B. (1985). Reclutamiento de la merluza y distribución y abundancia de varias especies comerciales en las Divisiones 1.4 y 1.5 durante 1983-1984. Colln scient. Pap. int. Commn SE. Atl. Fish. 12: 1-61

Magnuson. J. J., Crowder, L. B., Medvick, P. A. (1979). Tempcrature as an ecological resource. Am. Zool 19: 331-343

Marchand, J., Masson, G. (1989). Process of estuarine colonization by 0 -group sole (Solea solea): hydrological conditions, behaviour, and feeding activity in the Vilaine estuary. Rapp. P.-v. Réun. Cons. int. Explor. Mer 191: 287-295

Margalef, R. (1974). Ecología. Omega, Barcelona

Margalef, R. (1985). Introduction to the Mediterranean. In: Margalef, R. (ed.) Key environments. Western Mediterranean. Pergamon, Oxford, p. 1-16

Marliave, J. B. (1989). Epibenthic associations of Merluccius productus larvae with fjord walls. Rapp. P.-v. Réun. Cons. int. Explor. Mer 191: 146-152

Mas-Riera, J. (1990). Efectos ambientales en la estructura del sistema visual de los teleosteos. Ph. D. thesis, Univ. Barcelona

Mas-Riera, J., Lombarte, A., Gordoa, A., Macpherson, E. (1990). Influence of Benguela upwelling on the structure of demersal fish populations off Namibia. Mar. Biol. 104: $175-182$

Maso, M., Manriquez, M. (1987). Preliminary hydrological results of the 'Spanish Namibian Environmental Cruise' SNEC-II. Colln scient. Pap. int. Commn SE. A.tl. Fish. 14 $113-128$

Mauchline, J., Gordon, J. D. M. (1984). Diets and bathymetric distributions of the macrourid fish of the Rockall Trough, northeastern Atlantic Ocean. Mar. Biol. 81. 107-121

McCauley, R. W. Huggins, N. W. (1979). Ontogenetic and non-thermal seasonal effects on thermal preferenda of fish. Am. Zool. 19: 267-271

Middleton, R. W., Musick, J. A. (1986). The abundance and distribution of the family Macrouridae (Pisces: Gadiformes) in the Norfolk Canyon area. Fish. Bull. U.S. 84: 35-62

Norcross, B. L. Shaw, R. F. (1984). Oceanic and estuarine transport of fish eggs and larvae: a review. Trans. Am. Fish. Soc. 113: 153-165

Olivar, M. P. (1990). Spatial patterns of ichthyoplankton distribution in relation to hydrographic featurers in the Northern Benguela region. Mar. Biol. 106: 39-48

Olivar, M. P., Barangé, M. (1990). Zooplankton of the North-

This article was submitted to the editor ern Benguela region in a quiescent upwelling period. J. Plankton Res. 12: 1023-1044

Pearcy, W. G., Stein, D. L., Carney, R. S. (1982). The deep-sea benthic fish fauna of the North Eastern Pacific Ocean on Cascadia and Tufts abyssal plains and adjoining continental slopes. Biol. Oceanogr. 1: 375-428

Polloni, P. R., Haedrich, R., Rowe, G., Clifford, C. H. (1979). The size-depth relationship in deep ocean animals. Int. Rev. ges. Hydrobiol. 64: 39-46

Power, M. E. (1984). Depth distribution of armored catfish: predator-induced resource avoidance? Ecology 65: $523-528$

Richards, L. J. (1986). Depth and habitat distributions of three species of rockfish (Sebastes) in British Columbia: observations from the submersible PISCES IV Environm Biol. Fish. 17: 13-21

Roel, B. A., Macpherson, E. (1988). Feeding of Merluccius capensis and $M$. paradoxus off Namibia. S. Afr. J. mar. Sci. 6: $227-243$

Sabatés, A. (1990). Distribution patterns of larval fish populations in the Northwestern Mediterranean. Mar. Ecol. Prog. Ser. 59: 75-82

Salat, J., Font, J. (1987). Water mass structure near and offshore the Catalan coast during the winters of 1982 and 1983. Ann. Geophys. 198, 5B: 49-54

Shannon, L. V (1985). The Benguela ecosystem. 1. Evolution of the Benguela, physical features, and processes. In: Barnes, M. (ed.) Oceanography and marine biology. An annual review, 23. University Press, Aberdeen, p. $105-182$

Shulman, M. J., Ogden, J. C. (1987). What controls tropical reef fish populations: recruitment or benthic mortality? An example in the Caribbean reef fish fiemulon flavolineatum. Mar. Ecol. Prog. Ser. 39: 233-242

Siebenaller, J. F., Somero, G. N., Haedrich, R. L. (1982). Biochemical characteristics of macrurid fishes differing in their depths of distribution. Bial. Bull. mar. biol. Lab., Woods Hole 163: 240-249

Snelgrove, P. V R., Haedrich, R. L. (1985). Structure of the deep demersal fish fauna off Newfoundland. Mar. Ecol. Prog. Ser. 27: 99-107

Somero, G. N., Siebenaller, J. F., Hochachka, P. W. (1983) Physiological adaptations of deep-sea animals. In: Rowe, G. I (ed.) Deep-sea biology, Vol. 8, The sea. John Wiley and Sons, New York, p. 261-330

Sullivan, K. M. Somero, G. N. (1983). Size- and diet-related variations in enzymic activity and tissue composition in the sablefish, Anoplopoma fimbria. Biol. Bull. mar biol. Lab., Woods Hole 164: 315-326

Thiel, H. (1978). Benthos in upwelling regions. In: Boje, R., Thomczak, M. (eds.) Upwelling ecosystems. Springer-Verlag, Berlin, p. 124-138

Thiel, H. (1982). Zoobenthos of the CINECA area and other upwelling regions. Rapp. P.- v. Cons. int. Explor. Mer 180: 323-334

Till, R. (1974). Statistical methods for the earth scientist. An introduction. MacMillan, London

Torres, J. J., Somero, G. N. (1988). Metabolism, enzymic activities and cold adaptation in Antarctic mesopelagic fishes. Mar. Biol 98: 169-180

Manuscript first received: June 26, 1990

Revised version accepted: January 23, 1991 